\title{
IDENTIFIKASI GERAKAN MASSA TERHADAP KERUSAKAN JALAN RAYA SUKOREJO-WELERI KILOMETER 6-16 KABUPATEN KENDAL
}

\author{
Oleh: \\ Wahyu Widiyatmoko', Suhadi Purwantara ${ }^{2}$ \\ ${ }^{1}$ Mahasiswa S2 Geo-Information for Spatial Planning and Disaster Risk Management UGM \\ ${ }^{2}$ Staf Pengajar Jurusan Pendidikan Geografi FIS UNY \\ yoe.whie@gmail.com
}

\begin{abstract}
Abstrak
Penelitian ini bertujuan mengetahui: (1) Karakteristik gerakan massa, meliputi tipe, jumlah, dan distribusi keruangan, (2) Faktor yang penyebab dan pemicu gerakan massa, (3) Jenis kerusakan jalan pada setiap gerakan massa. Populasi dalam penelitian ini adalah lahan di sekitar jalan raya Sukorejo-Weleri Km 6-16. Sampel diambil secara purposive sampling yaitu tempat yang mengalami gerakan massa. Analisis data dengan analisis deskriptif, tetangga terdekat, dan analisis tabel. Hasil penelitian: (1) Gerakan massa terdiri atas tiga tipe, yaitu longsor rotasional, rayapan, dan jatuhan. Pola distribusi menyebar. (2) Longsor rotasional disebabkan kemiringan lereng miring-curam, solum tanah tebal, kekar, dan batuan melapuk sangat lanjut. Pemicu utamanya pemotongan kaki perbukitan. Rayapan disebabkan kemiringan lereng miring-curam dan kembang kerut tanah. Pemicu utamanya pembuatan teras bangku. Jatuhan disebabkan kemiringan lereng curam-sangat curam dan banyak rekahan batuan. Pemicunya air hujan yang masuk melalui rekahan. (3) Kerusakan jalan disebabkan longsor rotasional adalah timbunan material dan amblesan, rayapan berupa retakan dan jalan bergelombang, jatuhan berupa timbunan batuan.
\end{abstract}

Kata kunci: gerakan massa, jalan raya, kerusakan jalan

\begin{abstract}
This research aims at investigating: (1) Mass movement characteristics, that include type, amount, and spatial distribution, (2) Causes and trigger factors in every mass movement, (3) Damage road types in every mass movement. Population in this research consist of land around Sukorejo-Weleri road on kilometers 6-16. Samples were taken using purposive sampling techniques in places where mass movement occurred. Data analysis was performed through descriptive analysis, with nearest neighbour, and table analysis. The results are: (1) there are three types of mass movement, namely rotational slide, creep, and fall. Mass movement distributions are spreading. (2) rotational slide is caused by slope steep, soil solum thick, joint, and highly weathered rocks. The main trigger is hilly slope cut. Creep is caused by slope steep and soil heaving. The main trigger is stool terrace. Fall is caused by slope steep-very steep and a lot of rock fracture. Trigger factors include rain water that enter the rock fracture. (3) Road damages caused by rotational slide are soil heap and subsidence, caused by creep are road crack and wavy road, caused by fall is stone heap.
\end{abstract}

Keywords: mass movement, highway, road damage 


\section{PENDAHULUAN}

Indonesia memiliki banyak daerah pegunungan yang tersebar di berbagai wilayah. Daerah pegunungan merupakan daerah yang memiliki potensi bencana yang diakibatkan oleh gerakan massa (mass movement) lebih tinggi dibandingkan daerah dengan topografi datar. Gerakan massa tanah merupakan salah satu bencana alam yang sering melanda daerah perbukitan di daerah tropis basah (Hary Christady Hardiyatmo, 2006: 1). Gerakan massa merupakan gerakan ke arah bawah (gravitasi) material pembentuk lereng, yang dapat berupa tanah, batu, timbunan buatan atau campuran dari material lain (Hary Christady Hardiyatmo, 2006: 15).

Klasifikasi gerakan massa pembentuk lereng dapat dibagi menjadi lima macam, yaitu jatuhan (falls), robohan (topples), longsoran (slides), sebaran (spreads), dan aliran (flows) (Cruden dan Varnes, 1992 dalam Hary Christady Hardiyatmo, 2006: 15). Suharsono (1988 dalam Pramono dan Ashari, 2014) menjelaskan bahwa gerakan massa terjadi akibat adanya gaya gravitasi yang bekerja terhadap fragmen batuan hasil pelapukan, selanjutnya fragmen batuan tersebut menuruni lereng kemudian diendapkan pada tempat yang lebih rendah. Gerakan massa terjadi secara lebih intensif pada daerah pegunungan, terutama pada daerah yang memiliki kemiringan lereng besar dan pada saat musim hujan tiba. Gerakan massa mengakibatkan berbagai kerusakan pada lahan pertanian, bangunan rumah, dan berbagai infrastruktur, bahkan dapat menimbulkan korban jiwa. Dampak dari berbagai kerusakan yang diakibatkan oleh gerakan massa dapat berupa melumpuhnya kegiatan pembangunan dan aktivitas ekonomi pada daerah yang terkena bencana, maupun daerah di sekitarnya.

Jalan raya antara Sukorejo-Weleri termasuk dalam kategori jalan Provinsi, karena jalan ini menjadi bagian dari jalan kolektor yang menghubungkan antara satu kabupaten dengan kabupaten lain di Provinsi Jawa Tengah. Jalan Sukorejo-Weleri memiliki peran penting sebagai akses penghubung, terutama untuk masyarakat Kabupaten Temanggung dan Kabupaten Kendal bagian selatan dengan daerah sekitar pantai utara Jawa. Jalur ini menjadi poros perekonomian warga sekitar sebagai akses pemasaran hasil pertanian, hasil industri, bahan baku, jalur transportasi umum, dan sebagainya. Akibatnya, jalan ini cukup ramai dilewati oleh berbagai jenis kendaraan dari sepeda motor, mobil, truk, hingga bus besar. Jalan ini mempunyai nilai strategis bagi Pemerintah Provinsi Jawa Tengah.

Seperti karakteristik jalan di daerah pegunungan, jalan ini memiliki tanjakan dan turunan, serta berkelok-kelok, bahkan banyak ruas jalan yang berada di antara lereng terjal. Beberapa ruas jalan memiliki vegetasi yang cukup lebat di sebelah kanan dan kiri jalan. Vegetasi yang rapat dapat menambah beban berat bagi tanah sehingga dapat memicu terjadinya gerakan massa. Apabila musim hujan tiba, banyak ruas jalan yang terkena efek dari gerakan massa. Pada bagian lain, terdapat jalan yang retak-retak, tiang listrik yang miring dan batang pohon yang miring atau melengkung, menandakan jalur SukorejoWeleri ini rawan terjadi gerakan massa.

Geomorfologi sebagai ilmu pengetahuan yang berkaitan dengan bentuk lahan penyusunan muka bumi, baik di atas maupun di bawah permukaan air laut dan 
menekankan pada pembentukan dan perkembangan pada masa yang akan datang, serta konteksnya dengan lingkungan dan material yang membentuknya (Verstappen, 1985: 3). Gerakan massa merupakan suatu fenomena alam yang dapat dikaji menggunakan aspek geomorfologi karena berkaitan dengan bentuk lahan dan proses pembentukannya. Dalam geomorfologi terdapat empat aspek yang dipelajari yaitu morfologi, morfogenetik (proses), morfokronologi, dan morfoaransemen. Dengan menggunakan empat aspek geomorfologi tersebut dapat diidentifikasi faktor penyebab dan faktor pemicu gerakan massa pada suatu daerah.

Berdasarkan latar belakang tersebut, gerakan massa yang terjadi memberikan efek yang cukup besar pada kelancaran dan kenyamanan arus transportasi pada jalan raya Sukorejo-Weleri. Gerakan massa yang terjadi pada jalan raya Sukorejo-Weleri dapat dikaji menggunakan aspek geomorfologi. Dalam hal ini peneliti tertarik mengadakan penelitian dengan judul "Identifikasi Gerakan Massa (Mass Movement) Terhadap Kerusakan Jalan Raya Sukorejo-Weleri Km 6-16 Kabupaten Kendal Jawa Tengah".

\section{METODE}

Penelitian ini merupakan penelitian deskriptif dengan metode survei. Penelitian ini mengarah pada pengungkapan suatu masalah yang terjadi atau menggambarkan keadaan sebenarnya dengan cara mengungkapkan fakta-fakta dengan metode survei yang bersifat fisik. Populasi dalam penelitian ini adalah lahan yang berada di sekitar jalan raya SukorejoWeleri Km 6-16 Kabupaten Kendal. Sampel diambil dengan teknik purposive sampling yaitu tempat-tempat yang terlihat mengalami gerakan massa pada lahan di sekitar jalan raya Sukorejo-Weleri km 6-16. Gerakan massa yang terlihat akan menunjukkan ciri-ciri tertentu. Teknik pengumpulan data menggunakan observasi, pengukuran lapangan, dan pengumpulan data sekunder. Teknik analisis data menggunakan analisis deskriptif, analisis tetangga terdekat, dan analisis tabel.

\section{HASIL DAN PEMBAHASAN}

\section{Karakterisasi Gerakan Massa di Sekitar Jalan Sukorejo-Weleri Km 6-16}

Berdasarkan genesis dan morfologi dari bentuk lahan, daerah penelitian terdiri atas beberapa satuan bentuk lahan, yaitu:

a. Unit Bentuk Lahan Perbukitan Terkikis

Satuan bentuk lahan yang ada di daerah penelitian adalah perbukitan terkikis lereng miring, perbukitan terkikis lereng agak curam, dan perbukitan terkikis lereng curam.

b. Unit Bentuk Lahan Kaki Lereng

Satuan unit bentuk lahan yang ada di daerah penelitian adalah kaki lereng datar dan kaki lereng landai.

Hasil penelitian berdasarkan survei yang dilakukan di lapangan menunjukkan terdapat tiga jenis gerakan massa yang ditemui peneliti, yaitu jatuhan, longsor rotasional, dan rayapan. Gerakan massa tipe jatuhan terdapat empat kejadian, longsor rotasional terdapat sepuluh kejadian, sedangkan rayapan terdapat enam kejadian (Tabel 1). Distribusi gerakan massa tipe longsor rotasional pada bentuklahan perbukita terkikis memiliki pola 
menyebar cenderung linier sepanjang jalan raya Sukorejo-Weleri. Hal ini disebabkan oleh adanya faktor pemicu gerakan massa tipe longsor rotasional, yaitu pemotongan kaki perbukitan untuk pembangunan jalan dan pembuatan teras untuk lahan pertanian. Distribusi gerakan massa tipe rayapan pada bentuk lahan perbukitan terkikis memiliki pola distribusi menyebar cenderung linier sepanjang jalan raya Sukorejo-Weleri. Hal ini disebabkan oleh adanya faktor pemicu gerakan massa tipe rayapan, yaitu pembuatan teras untuk lahan pertanian dan beban karena vegetasi yang rapat. Distribusi gerakan massa tipe jatuhan pada bentuk lahan perbukitan terkikis memiliki pola menyebar cenderung linier sepanjang jalan raya Sukorejo-Weleri. Hal ini disebabkan oleh adanya faktor pemicu gerakan massa tipe jatuhan, yaitu pemotongan kaki perbukitan untuk pembangunan jalan.

Tabel 1. Tipe Gerakan Massa pada Setiap Bentuklahan

\begin{tabular}{|c|c|c|c|c|}
\hline No & Bentuklahan & Tipe Gerakan Masa & Jumlah Kejadian & Persentase \\
\hline \multirow{3}{*}{1} & \multirow{3}{*}{$\begin{array}{l}\text { Perbukitan Terkikis } \\
\text { Lereng Miring }\end{array}$} & Jatuhan & 1 & 5 \\
\hline & & Longsor rotasional & 2 & 10 \\
\hline & & Rayapan & 3 & 15 \\
\hline \multirow{3}{*}{2} & \multirow{3}{*}{$\begin{array}{l}\text { Perbukitan Terkikis } \\
\text { Lereng Agak Curam }\end{array}$} & Jatuhan & 2 & 10 \\
\hline & & Longsor rotasional & 5 & 25 \\
\hline & & Rayapan & 2 & 10 \\
\hline \multirow{3}{*}{3} & \multirow{3}{*}{$\begin{array}{l}\text { Perbukitan Terkikis } \\
\text { Lereng Curam }\end{array}$} & Jatuhan & 1 & 5 \\
\hline & & Longsor rotasional & 3 & 15 \\
\hline & & Rayapan & 1 & 5 \\
\hline \multicolumn{3}{|c|}{ Jumlah Kejadian Gerakan Massa } & 20 & 100 \\
\hline
\end{tabular}

Sumber: Data Lapangan (2013)

\section{Faktor Penyebab dan Pemicu Gerakan Massa}

Longsor rotasional pada bentuklahan perbukitan terkikis dengan lereng miring memiliki faktor penyebab berupa tekstur tanah geluh berlempung, kedalaman solum tanah 90-150, drainase tanah baik, dan pelapukan batuan sangat lanjut. Adapun faktor yang dominan penyebab longsor rotasional adalah pemotongan kaki perbukitan untuk dibuat jalan. Longsor rotasional yang terjadi juga disebabkan karena penggunaan lahan berupa sawah dimana genangan air yang ada dapat menambah beban dan memperlicin batuan dasar sehingga memicu terjadinya longsor rotasional.

Kejadian longsor rotasional pada bentuklahan perbukitan terkikis dengan lereng agak curam, faktor penyebabnya adalah kelas relief bergelombang hingga berbukit, tekstur tanah geluh berlempung, kedalaman solum 90-150 cm, drainase tanah agak baik hingga baik, dan pelapukan batuan sangat lanjut. Adapun faktor pemicunya adalah pemotongan kaki perbukitan untuk dibuat jalan. Akibat lain karena adanya pemotongan kaki perbukitan menyebabkan material hasil longsor terendapkan mendekati jalan. Gambar 1 menunjukkan kenampakan longsor yang terjadi pada perbukitan terkikis dengan lereng agak curam.

Longsor rotasional pada bentuklahan perbukitan terkikis dengan lereng curam dipengaruhi faktor penyebab berupa kemiringan lereng $25^{\circ}-45^{\circ}$, bentuk lereng cekung, kelas relief berbukit, tekstur tanah geluh berlempung, kedalaman solum 90-150 cm, 
drainase tanah baik, dan pelapukan batuan sangat lanjut. Longsor yang terjadi memiliki daya rusak yang tinggi karena skala longsornya yang cukup besar. Adapun faktor pemicunya adalah beban vegetasi yang rapat. Selain itu, adanya pemotongan kaki perbukitan untuk dibuat jalan semakin memperbesar potensi resiko terjadinya longsor. Gambar 2 menunjukkan kenampakan longsor yang terjadi pada perbukitan terkikis dengan lereng curam.

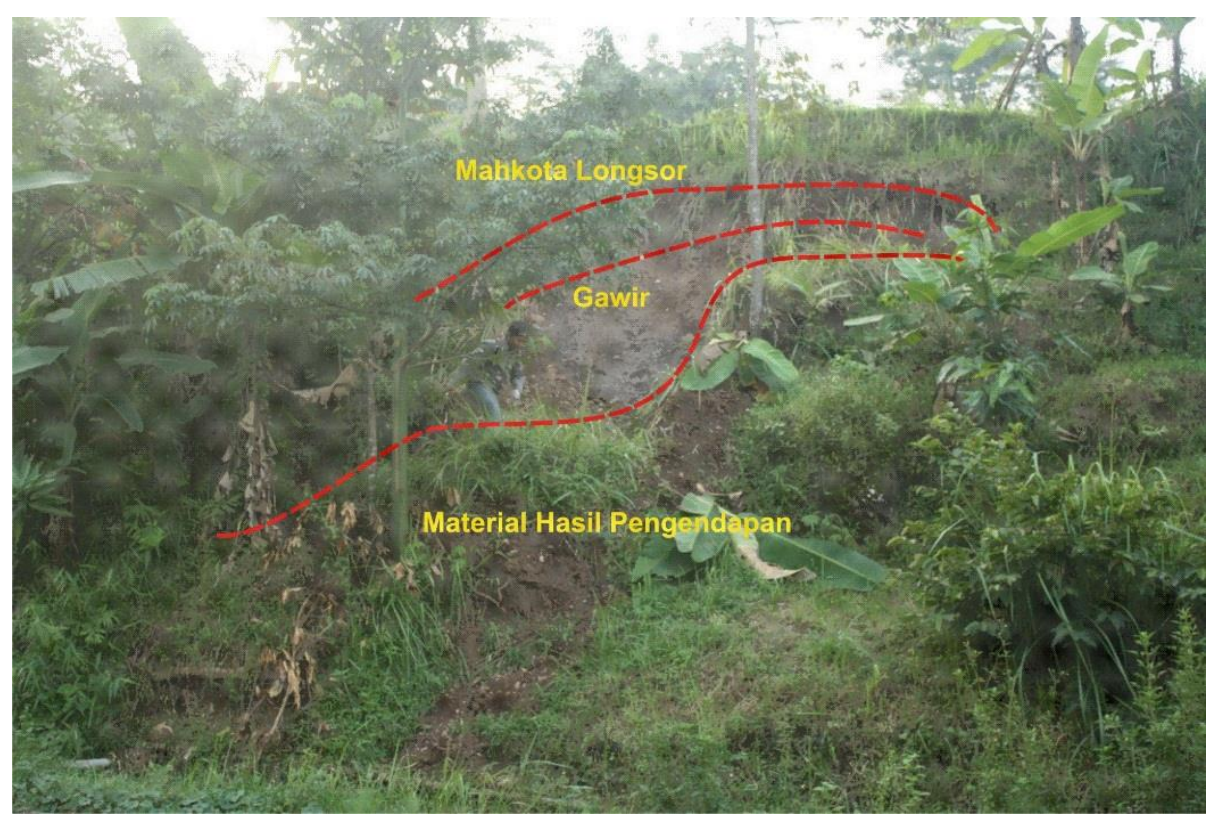

Gambar 1. Longsor pada perbukitan terkikis dengan lereng agak curam.

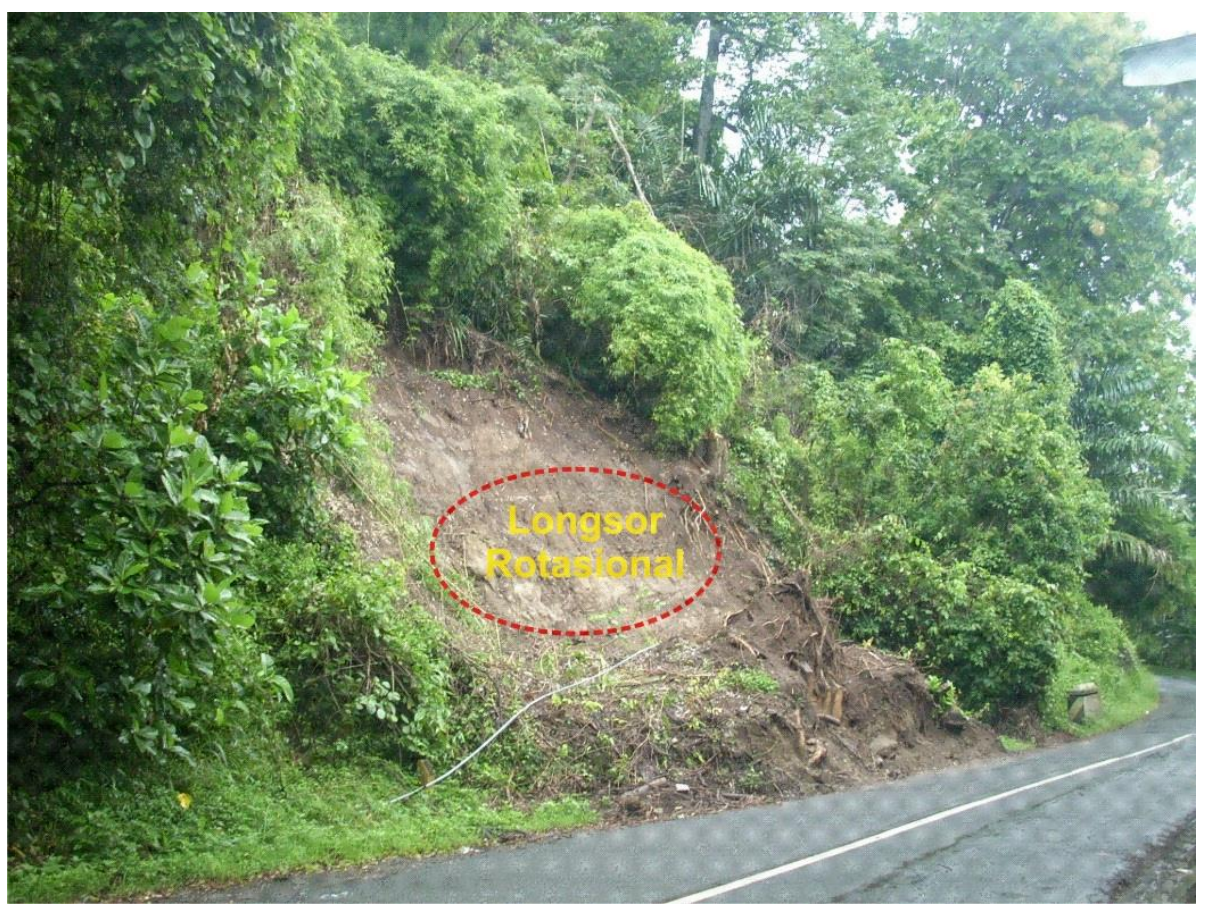

Gambar 2. Longsor pada perbukitan terkikis dengan lereng curam. 
Rayapan pada bentuklahan perbukitan terkikis dengan lereng miring dipengaruhi faktor penyebab berupa kemiringan lereng tekstur tanah geluh berlempung, kedalaman solum 60-90 cm, drainase tanah agak baik sampai baik, dan tanah dapat berkembang kerut. Faktor pemicunya adalah Pembuatan teras bangku untuk sawah dan kebun dapat memicu terjadinya gerakan massa tipe rayapan karena teras bangku memungkinkan lebih banyak air yang masuk ke dalam tanah sehingga pori-pori tanah akan terisi lebih banyak.

Rayapan pada bentuklahan perbukitan terkikis dengan lereng agak curam faktor penyebabnya dari aspek morfologi adalah kelas relief bergelombang hingga berbukit, tekstur tanah geluh berlempung, kedalaman solum $60-90 \mathrm{~cm}$, drainase tanah baik, tanah dapat berkembang kerut, dan pelapukan batuan sangat lanjut, sedangkan faktor pemicunya adalah penggunaan lahan yang berupa kebun. Kenampakan rayapan di lapangan ditunjukkan oleh Gambar 3.

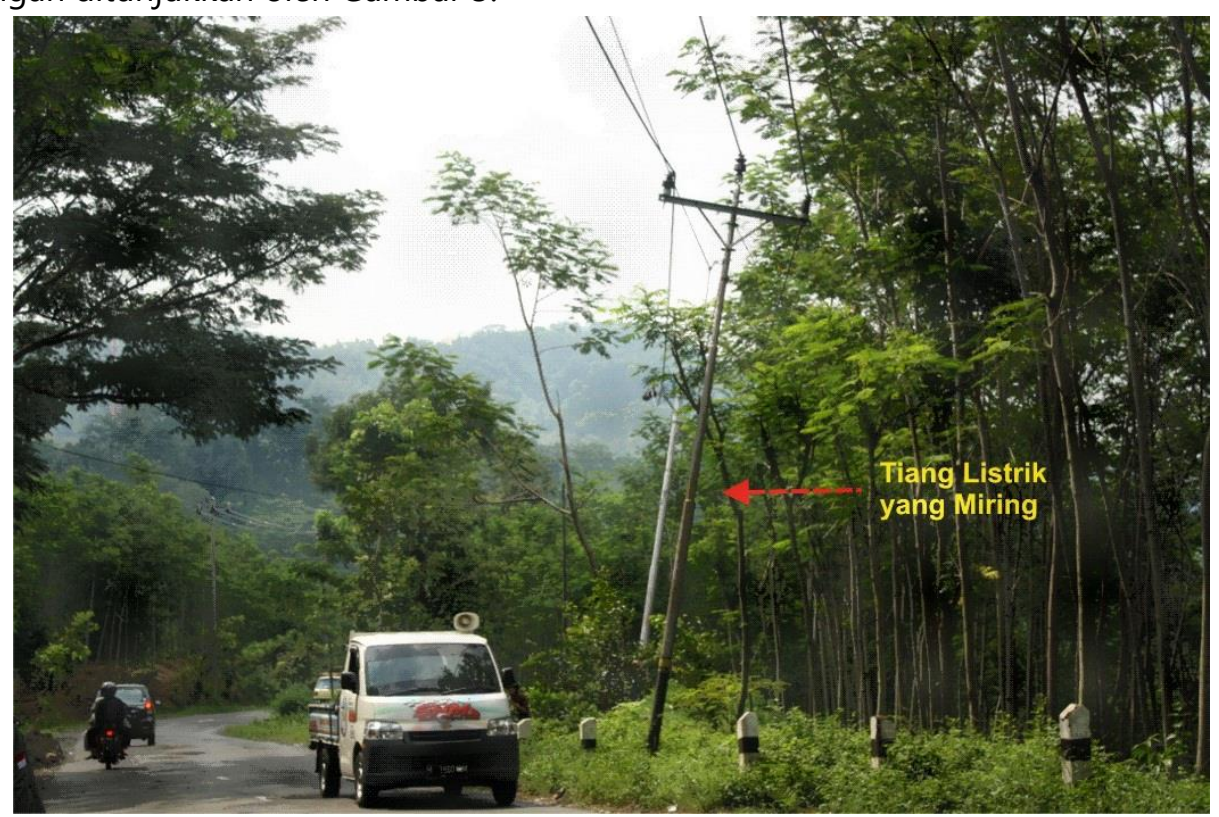

Gambar 3. Kenampakan rayapan dengan Indikator Jalan Retak dan Tiang listrik Miring

Rayapan pada bentuklahan perbukitan terkikis dengan lereng curam dikendalikan oleh faktor penyebab dari aspek morfologi adalah kemiringan lereng $25^{\circ}-45^{\circ}$, bentuk lereng cembung, kelas relief berbukit. Aspek morfostruktur pasif adalah tekstur tanah geluh berlempung, kedalaman solum 60-90 cm, drainase tanah baik, tanah dapat berkembang kerut, pelapukan batuan sangat lanjut. Adapun faktor pemicu adalah penggunaan lahan yang berupa hutan. Kerapatan vegetasi yang tinggi menyebabkan beban tanah semakin besar. Kemiringan lereng yang besar dengan beban yang berat memungkinkan tanah bergerak ke bawah lebih cepat.

Jatuhan pada bentuklahan perbukitan terkikis dipengaruhi oleh faktor penyebab dari aspek morfologi adalah kemiringan lereng $45^{\circ}-70^{\circ}$. Pada aspek morfostruktur pasif adalah batuan yang sudah sangat lapuk yang ditandai dengan pengelupasan bagian luar dari batuan sehingga bagian luar dari batuan ini dapat dengan mudah terlepas. Sementara itu 
faktor pemicunya adalah penggunaan lahan berupa hutan dan kebun. Hal ini mengakibatkan banyak akar tanaman yang masuk ke dalam rekahan dan memperbesar rekahan. Pengelolaan lahan berupa pemotongan kaki perbukitan untuk dibuat jalan raya. Hujan yang terjadi secara intensif pada daerah penelitian dapat memicu gerakan massa tipe jatuhan karena air hujan dapat mengisi rekahan pada batuan.

\section{Kerusakan Jalan raya Sukorejo-Weleri Km 6-16 Karena Gerakan Massa}

Kerusakan yang diakibatkan oleh gerakan massa tipe longsor rotasional terdapat dua jenis, yaitu timbunan dan amblesan. Timbunan terjadi apabila tanah yang mengalami longsor lebih tinggi dari jalan sehingga tanah yang longsor menimbun ruas jalan. Kerusakan ini dapat diatasi dengan memindahkan timbunan material pada ruas jalan ke tempat lain. Amblesan terjadi apabila tanah yang mengalami longsor adalah tanah pada jalan itu sendiri sehingga material tanah bergerak turun menyebabkan amblesan pada jalan. Kerusakan pada jalan hanya dapat diatasi oleh tim teknis untuk memperbaiki konstruksi jalan.

Kerusakan jalan yang diakibatkan oleh gerakan massa tipe rayapan adalah retakan pada jalan dan senderan jalan serta jalan yang bergelombang. Kerusakan jalan akibat rayapan terjadi secara perlahan dengan wilayah lebih luas dibandingkan longsor rotasional dan jatuhan. Kerusakan jalan karena rayapan hanya dapat diatasi oleh tim teknis yang memperbaiki konstruksi jalan, yaitu dengan memperdalam fondasi jalan.

Gerakan massa tipe jatuhan menyebabkan kerusakan pada jalan raya berupa timbunan batuan. Batuan yang jatuh berada dari lereng atas kemudian berhenti di area jalan. Hubungan antara tipe gerakan massa dan kerusakan jalan raya Sukorejo-Weleri dapat dilihat pada Tabel 2. Jumlah kejadian gerakan massa yang menimbulkan kerusakan jalan terdapat pada Tabel 3. Distribusi tipe kerusakan lahan akibat gerakan massa ditunjukkan oleh Gambar 4.

Tabel 2. Hubungan antara Tipe Gerakan Massa dan Jenis Kerusakan Jalan

\begin{tabular}{|l|l|}
\hline \multicolumn{1}{|c|}{ Tipe Gerakan Massa } & \multicolumn{1}{c|}{ Jenis Kerusakan Jalan } \\
\hline Longsor Rotasional & Amblesan dan penimbunan material pada jalan \\
\hline Rayapan & Retakan \\
\hline Jatuhan & Penimbunan batuan \\
\hline
\end{tabular}

Sumber: Hasil analisis data primer 2013

Tabel 3. Jumlah Kejadian Gerakan Massa yang Menimbulkan Kerusakan Jalan

\begin{tabular}{|c|l|c|r|}
\hline No & \multicolumn{1}{|c|}{ Tipe Gerakan Massa } & $\begin{array}{c}\text { Jumlah Kejadian yang } \\
\text { Merusak Jalan }\end{array}$ & Persentase \\
\hline 1 & Longsor Rotasional & 6 & 50,0 \\
\hline 2 & Rayapan & 5 & 41,7 \\
\hline 3 & Jatuhan & 1 & 8,3 \\
\hline \multicolumn{2}{|c|}{ Jumlah } & 12 & 100,0 \\
\hline
\end{tabular}


Sumber: Hasil analisis data primer 2013

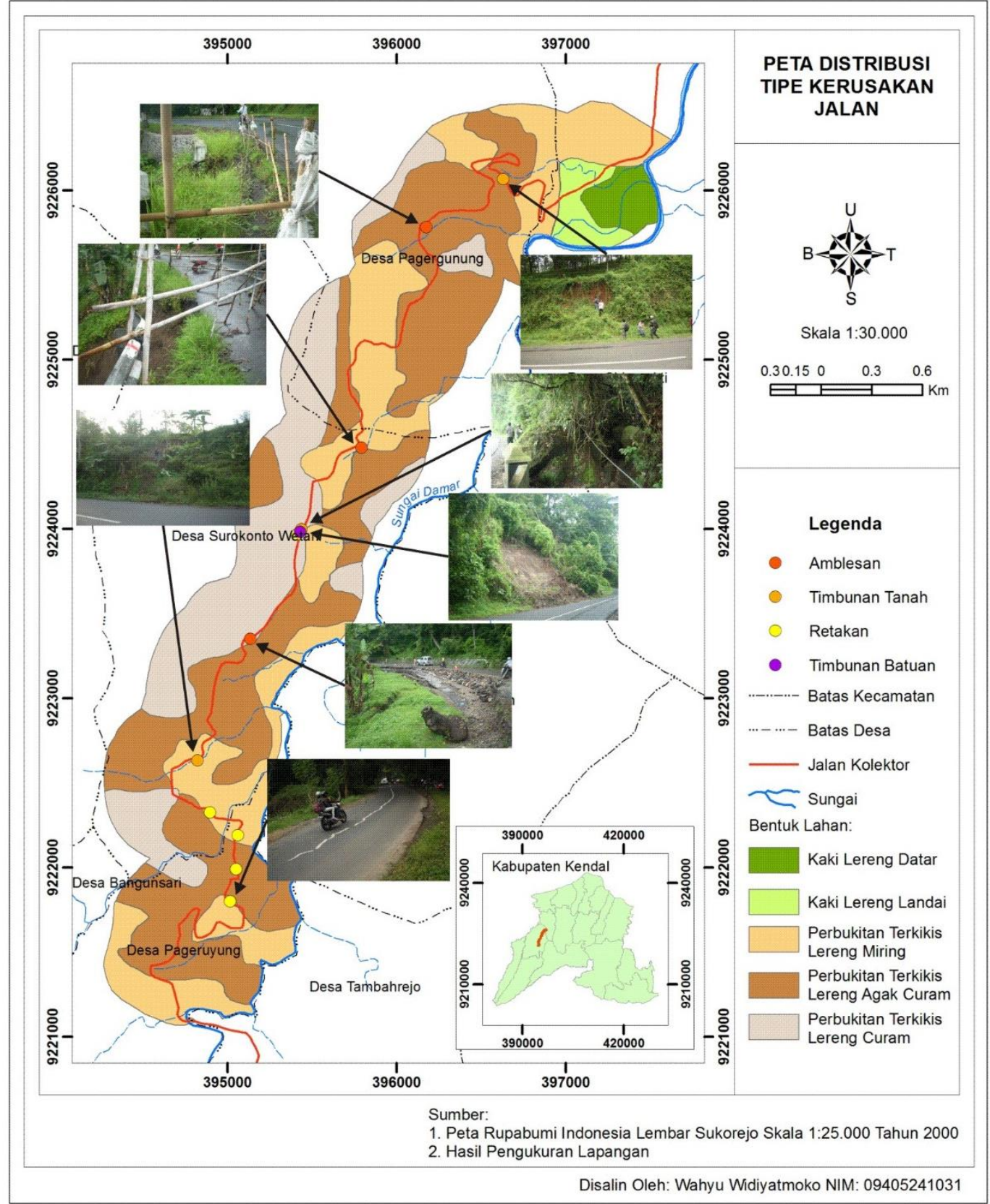

Gambar 4. Distribusi Tipe Kerusakan Lahan Akibat Gerakan Massa

\section{SIMPULAN}

Berdasarkan hasil dan pembahasan penelitian, dapat disimpulkan bahwa:

1. Gerakan massa yang terjadi pada daerah penelitian terdiri atas 3 tipe gerakan massa, yaitu longsor rotasional, rayapan, dan jatuhan. Longsor rotasional dan jatuhan paling banyak ditemui pada bentuk lahan perbukitan terkikis lereng agak curam, sedangkan rayapan paling banyak ditemui pada bentuk lahan perbukitan terkikis lereng miring. Jumlah kejadian gerakan massa tipe longsor rotasional adalah sepuluh kejadian, 
rayapan enam kejadian, dan jatuhan empat kejadian. Pola distribusi untuk gerakan massa tipe longsor rotasional, rayapan, dan jatuhan adalah menyebar.

2. Gerakan massa tipe longsor rotasional disebabkan oleh kemiringan lereng termasuk miring-curam, solum tanah yang tebal, terdapat kekar, dan batuan yang melapuk sangat lanjut. Pemicu utamanya adalah pemotongan kaki perbukitan, terutama untuk dibuat jalan. Gerakan massa tipe rayapan disebabkan oleh kemiringan lereng miring-curam, terjadi kembang kerut pada tanah. Pemicu utamanya adalah pembuatan teras bangku pada perkebunan dan sawah. Gerakan massa tipe jatuhan terjadi pada kemiringan lereng curam-sangat curam dan banyak terdapat rekahan pada batuan. Pemicunya adalah air hujan yang masuk melalui rekahan.

3. Kerusakan jalan raya Sukorejo-Weleri yang disebabkan oleh longsor rotasional adalah timbunan material dan amblesan di tepi jalan. Jenis kerusakan yang disebabkan oleh rayapan berupa retakan pada jalan dan senderan jalan serta jalan yang bergelombang. Kerusakan jalan akibat jatuhan adalah timbunan batuan pada tepi jalan.

\section{UCAPAN TERIMA KASIH}

Tulisan ini merupakan bagian dari penelitian tugas akhir skripsi yang berjudul Identifikasi Gerakan Massa (Mass Movement) Terhadap Kerusakan Jalan Raya SukorejoWeleri Kilometer 6-16 Kabupaten Kendal di Jurusan Pendidikan Geografi FIS UNY. Penulis mengucapkan terima kasih kepada berbagai pihak yang telah membantu dalam proses penelitian, terutama kepada tim survei lapangan, Saudara Sujarwo, S.Pd., Taufik Walinono, S.Pd., Hermawan Kuswantoko, S.Pd., Toffan Hussein Widyarmoko, S.Pd., Wahyu Mardiyanto, S.Pd, Fajar Agung Nugroho, S.Pd., dan Sentot Catur Pamungkas, S.Pd., serta terima kasih kepada Bapak Arif Ashari, M.Sc. atas ide dan masukan untuk pelaksanaan penelitian. Penulis juga menghaturkan terima kasih sebesar-besarnya kepada pembimbing tugas akhir, Bapak Suhadi Purwantara, M.Si., atas bimbingan yang telah diberikan.

\section{DAFTAR PUSTAKA}

Hary Christady Hardiyatmo. 2006. Penanganan Tanah Longsor dan Erosi. Yogyakarta: Gadjah Mada University Press.

Pramono, H. dan Ashari, A. 2014. Geomorfologi Dasar. Yogyakarta: UNY Press

Verstappen, H. Th. (1985). Applied Geomorphology. Enschede: International Institute for Aerial Survey and Earth Science (ITC). 